\title{
O rozwoju graficznych języków komunikacji. Przykład wykorzystania UML w obszarze bibliologii i informatologii
}

\author{
Anna Małgorzata Kamińska \\ Instytut Bibliotekoznawstwa i Informacji Naukowej, Uniwersytet Śląski
}

\begin{abstract}
Abstrakt
Cel/Teza: Celem artykułu jest przybliżenie koncepcji Unified Modeling Language (UML) oraz możliwości jego użycia w dziedzinie bibliologii i informatologii.

Koncepcja/Metody badań: Na podstawie analizy piśmiennictwa omówiony został proces kształtowania się języków graficznych oraz ich zalety związane z zapewnieniem zwięzłości i precyzji komunikacji. Analiza przypadku kategoryzacji wydawnictw wykorzystana została do zademonstrowania zasad modelowania pojęć z dziedziny bibliologii i informatologii za pomocą języka UML.

Wyniki i wnioski: Przedstawiony przykład modelowania za pomocą UML pojęć z zakresu bibliologii i informatologii pokazuje przydatność tego języka w opracowywaniu nowych metod i narzędzi dla bibliotekarstwa i usług informacyjnych.

Oryginalność/Wartość poznawcza: Chociaż UML jest narzędziem szeroko stosowanym w wielu dziedzinach, w piśmiennictwie nauki o informacji nie analizowano dotychczas jego przydatności do modelowania narzędzi i usług informacyjnych.
\end{abstract}

\section{Słowa kluczowe}

Język graficzny. Komunikacja. Notacja graficzna. UML. Unified Modeling Language.

Otrzymany: 31 marca 2017. Zrecenzowany: 7 października 2017. Poprawiony: 31 października 2017.

Zrecenzowany: 19 grudnia 2017. Poprawiony: 4 września 2018. Zaakceptowany: 15 grudnia 2018.

\section{Wprowadzenie}

Mechanizmy komunikacyjne, podobnie jak i inne wykształcone na drodze ewolucji, cechują się lokalnymi kierunkami przystosowania, tzn. ewoluują w stronę zaspokajania potrzeb konkretnych społeczności, które mogą być różne w zależności od ich lokalizacji geograficznej, dostępności surowców i innych zasobów czy też obecności społeczności konkurujących o przestrzeń i surowce. W przypadku ludzi, których duże potrzeby komunikacyjne doprowadziły do wykształcenia różnych języków etnicznych z odmiennym słownictwem, gramatyką i kontekstem, doprowadziło to do problemów komunikacyjnych pomiędzy poszczególnymi społecznościami.

Drugą konsekwencją ewolucyjnego powstawania języka jest redundantność jego przekazu, na co miała wpływ zapewne potrzeba zmniejszenia jego podatności na powstawanie błędów w komunikacji (Piantadosi et al., 2011). Błędy te mogły być powodowane przez osobnicze różnice w budowie aparatu głosowego, hałas lub inne zakłócenia ośrodka przekazu, potrzebę przesyłania komunikatów na większe odległości itp. Szczegółowymi aspektami źródeł tej 
redundancji i jej skutków, tak pozytywnych jak i negatywnych, zajmują się językoznawcy, a podstawowe informacje z tej dziedziny przedstawiają np. Ernst Wit oraz Marie Gillette (Wit \& Gillette, 1999). Warto zauważyć, że w warunkach kontrolowanej jakości środków przekazu (brak zakłóceń akustycznych, czytelne wydruki, monitory ekranowe o wyraźnym obrazie, itp.) niektóre powody istnienia redundancji językowych tracą rację bytu i niosą niepotrzebny balast, jednak w praktyce codziennej komunikacji międzyludzkiej redundancja jako taka jest niezbędna. Problemem jest zatem jej poziom, a nie jej istnienie lub jej brak.

Języki naturalne powstawały zatem w celu i w warunkach, dla których zapewnienie globalnej zrozumiałości i zwięzłości przekazu nie było istotne. Jednak rozwój cywilizacyjny ludzkości od epoki maszyn parowych, poprzez globalną elektryfikację, aż po rewolucję informacyjną, spowodował wzrost popytu na mechanizmy komunikacji i utrwalania informacji w postaciach zwięzłych i zrozumiałych niezależnie od pochodzenia kulturowego. Czynniki te wpłynęły zapewne w decydującym stopniu na rozwój alternatywnych języków czy też notacji graficznych ${ }^{1}$.

Język graficzny na potrzeby niniejszych rozważań został zdefiniowany jako język, którego wypowiedzi mają formę graficzną i jest to pierwotna forma tych wypowiedzi. Odróżnia to języki graficzne od języków naturalnych, których głównym subkodem jest subkod wokalny, a wypowiedzi w formie graficznej pełnią rolę wtórną. Języki graficzne wykorzystują najczęściej symbole graficzne składające się z elementarnych figur geometrycznych (np. linii, okręgów, wielokątów). Zestawienie i/lub łączenie tych symboli służy tworzeniu wyrażenia niosącego pewną informację. W wielu językach graficznych jest też możliwe wplatanie w strukturę takiego wyrażenia symboli alfanumerycznych, słów z pewnego języka naturalnego, a nawet i dłuższych wypowiedzi.

Choć języki graficzne znajdują obecnie zastosowanie głównie w dziedzinach technicznych, to od pewnego czasu obserwować można ich wykorzystanie w innych gałęziach. Kilkanaście lat temu początkowy brak zainteresowania tymi językami sygnalizowała Małgorzata Stanula-Boroń (Stanula-Boroń, 2001) zauważając, że bywają one niedoceniane. Obecnie języki te usprawniają komunikację w wielu obszarach, np. w medycynie (Venot et al., 2008; Lamy et al., 2005) czy przemyśle (Dietsch et al., 2011). Przykład wykorzystania formalnego języka graficznego (Grafoo) do opisu zbioru ontologii publikacji i ich cytowań SPAR (The Semantic Publishing and Referencing Ontologies) przedstawiłam za jej twórcami przy okazji omówienia usług otwartego dostępu do indeksu cytowań (OpenCitations Corpus) (Kamińska, 2017a). Warto zwrócić uwagę na mnogość technik graficznego definiowania ontologii, w przeglądzie których (Slimani, 2015), zawierającym również odniesienie do języka Grafoo, autor stwierdza, że język UML jest nazbyt zredukowany i że języki bardziej rozbudowane pozwalają na lepszą reprezentację ontologii. Warto zauważyć, że stwierdzenie to stoi w opozycji do opinii wyrażanych przez wielu użytkowników języka UML, którzy jego prostotę postrzegają jako zaletę, która nie musi ograniczać możliwości jego stosowania, gdyż w języku tym istnieją mechanizmy pozwalające na jego rozszerzanie odpowiednio do własnych potrzeb.

1 W ramach artykułu pojęcia notacja i język graficzny używane są zamiennie, choć w szerszym rozumieniu notacje graficzne dotyczą nie tylko symboli graficznych, ale np. również alfanumerycznych. W odniesieniu do języków graficznych notacja definiowana bywa również jako materializacja jego składni, czyli określenie graficznej reprezentacji poszczególnych elementów danego języka (Olczyk, 2010). 
Przykłady zastosowania diagramów klas języka UML dla opisów ontologii, taksonomii oraz do doprecyzowania informacji wyrażanych innymi nieformalnymi notacjami graficznymi znaleźć można w innym moim opracowaniu (Kamińska, 2018b), natomiast wykorzystanie diagramu przypadków użycia do modelowania interakcji użytkownika z bibliograficzną bazą danych przedstawiłam w (Kamińska, 2017b).

\section{Rozwój języków graficznych}

Najstarszymi znanymi formami graficznymi wytworzonymi przez człowieka są ryty i malowidła naskalne, które datuje się na dziesiątki tysięcy lat. Motywacje ich tworzenia przez ówczesnych ludzi nie są do końca poznane, a tezy zawarte w podręcznikach historii opisujących tamte odległe czasy i ujęcia tego zagadnienia przeredagowywano już kilkakrotnie. Rozważając początki języków graficznych można zadać sobie pytanie czy wspomniane formy, określane również często jako jedne z pierwszych przejawów sztuki prehistorycznej, mieszczą się w definicji języka. Biorąc pod uwagę mnogość tych definicji można tutaj przywołać jedną z najszerszych (Drabik \& Sobol, 2016):

sposób porozumiewania się ludzi pewnego środowiska lub zawodu oraz zapisu i przekazywania informacji w jakiejś dziedzinie wiedzy.

Przyjmując, że najnowsze badania funkcji społecznych tych najwcześniejszych form komunikacji graficznej wskazują na rolę obrazowania poglądu na porządek panujący w naturze, uznać można, że funkcje te mieszczą się w przytoczonej definicji języka.

Analizując ewolucję technik komunikacyjnych gatunku ludzkiego można zauważyć, że początkowo rozwijające się równolegle przekazy głosowe i graficzne w większości przypadków zbiegły się w pewnym momencie, przy czym przekaz głosowy zyskał status nadrzędny, a pismo stało się narzędziem wtórnym, które bywało do niego dostosowane (sytuacja taka widoczna jest w przypadku języków z pismem fonograficznym). Ponieważ utrwalone takim pismem procesy poznawcze muszą przejść dwukrotną transformację formy nośnika informacji, to w niektórych przypadkach mogą powodować rozmycie precyzji opisu. Dla przykładu, rysunek trójkąta i koła o ścisłym położeniu tych figur na płaszczyźnie z określonymi układami współrzędnych, po raz pierwszy przechodzi transformację w przypadku zidentyfikowania i zaklasyfikowania tych obiektów przez człowieka oraz nadania im nazw w języku, którym ten człowiek posługuje się (czyli wytworzeniu jego modelu pojęciowego oznaczonego etykietą językową). Druga transformacja następuje w sytuacji utrwalenia tego modelu pismem opisującym utrwalany model z perspektywy dźwiękowego brzmienia opisującej go wypowiedzi. O ileż prościej i na pewno bardziej precyzyjnie byłoby po prostu skopiować opisywany obrazek w celu przekazania go odbiorcy!

Spostrzeżenia te stały się szczególnie istotne wraz z nastaniem epoki renesansu, a z nią gwałtownym rozwojem architektury oraz początkami innych dyscyplin inżynierii, dając podstawy rysunkowi technicznemu (Tarełko, 2014). Używano go do dokumentowania i projektowania struktur złożonych za pomocą narzędzi kreślarskich, a główne jego formy abstrakcji stanowiły skala oraz rzuty. Powstające modele były bardzo dosłowne i brakowało im elementów opisujących zachowanie czy dynamikę reprezentowanych obiektów i konstrukcji. Sytuacja zaczęła się zmieniać gwałtownie wraz z nastaniem rewolucji 
informacyjnej, kiedy to zaistniała potrzeba wyrażania pojęć nie tylko z dziedzin inżynierii, produktów, których obecność może być namacalna, ale idei bardziej ulotnych, wykraczających poza fizyczną percepcję człowieka i niejednokrotnie wchodzących w skład złożonych systemów pojęciowych.

\section{Współczesne notacje graficzne}

Współczesne języki graficzne są językami sztucznymi, tj. utworzonymi celowo do zapewnienia optymalnie sprawnej komunikacji w określonym zakresie. Języki te podlegały jednak także pewnemu procesowi ewolucji. Początek zainteresowania sztucznymi językami graficznymi zbiega się z początkiem światowej rewolucji informacyjnej. Początkowo, w latach 70. XX w., kierunki rozwoju tych języków stymulowane były przez nauki techniczne, w tym potrzebę modelowania struktury otaczającego nas świata i zależności występujących pomiędzy jego bytami, dla potrzeb projektowania struktur baz danych. Naukowcy i inżynierowie potrzebowali zwięzłych i czytelnych metod opisu złożoności modelowanych systemów. Mimo że pierwsze rozwiązania w zakresie tworzenia takich notacji nie dawały tak dużych korzyści jak notacje używane współcześnie, to i tak stanowiły istotny postęp w rozwoju języków graficznych. Często przyjmuje się, że pierwszym ważnym krokiem w ich rozwoju było wprowadzenie pojęć encji i relacji przez Petera Chena (Chen, 1976) z Massachusetts Institute of Technology. Mimo dużego zainteresowania tym nowym wówczas podejściem, jego szybkim rozwojem i niekwestionowaną przydatnością praktyczną (do końca lat 90. XX w. było to najczęściej stosowane podejście w modelowaniu struktur danych, a praktyczne zastosowanie znajduje nawet po dzień dzisiejszy), z perspektywy czasu łatwo zauważyć jego niedostatki i ograniczenia. Polegały one w głównej mierze na koncentrowaniu się na perspektywie strukturalnej (stąd w literaturze podejście to nazywane bywa metodyką strukturalną), z pominięciem aspektów behawioralnych. Drugim niedostatkiem jest zbytnie uproszczenie postrzegania relacji zachodzących pomiędzy encjami, gdyż brak tutaj możliwości zobrazowania kierunku relacji, wyróżnienia relacji typu część-całość, a przede wszystkim możliwości wyrażania relacji abstrakcji. Bardziej szczegółowy opis rozwoju tego podejścia przedstawia jego twórca w swoim przeglądowym artykule (Chen, 2002).

Brak możliwości opisu aspektów behawioralnych nie był traktowany jako istotny problem, ponieważ wcześniej istniały już inne języki graficzne, które tworzono w celu modelowania takich aspektów rzeczywistości. Były to na przykład schematy blokowe (ang. flowcharts), których początki datuje się na lata 20. XX w., a ich wprowadzenie przypisuje się Frankowi i Lillian Gilbrethom (Gilbreth \& Gilbreth, 1921) oraz diagramy przepływu danych (ang. data flow diagrams) umożliwiające graficzne wyrażanie modeli nie tylko przepływów danych w systemach komputerowych, ale również przepływów informacji w instytucjach czy ogólnie - wszelkich podsystemach operujących na zbiorze encji. Powstanie tego podejścia datuje się na lata 70. XX w., kiedy to opisano je po raz pierwszy w artykule Structured Design (Stevens et al., 1974).

Poza wcześniej wymienionymi, najbardziej rozpowszechnionymi notacjami, od początku rewolucji informacyjnej rozwijało się również wiele innych języków graficznych, które projektowano, aby rozwiązać problemy opisu rzeczywistości, z którymi nie radziły sobie te 
powszechnie stosowane notacje. Były to m.in. diagramy FFBD (ang. Functional Flow Block Diagram), mapy procesów (ang. Business Process Mapping) i wiele innych, które łączyła wspólna słabość polegająca na wyrażaniu rzeczywistości z perspektywy, do obsługi której zostały stworzone, ale w oderwaniu od opisów tejże rzeczywistości w innych perspektywach. Przykładowo, diagramy przepływu danych opisują perspektywę procesową systemów (np. w bibliotece czytelnicy generują strumienie danych dotyczących zamawianych publikacji, które są przetwarzane przez bibliotekarzy i skutkują odnotowaniem odpowiednich informacji na karcie/koncie czytelnika), ale nie dają możliwości przedstawienia ich perspektywy strukturalnej (publikacje są bytami abstrakcyjnymi, które posiadają swoje konkretne egzemplarze, z których część jest dostępna, a część właśnie wypożyczona/ udostępniona). Warto tutaj zauważyć, że mimo opisanych ograniczeń i związanego z nimi spadku zainteresowania diagramami przepływu danych, okazują się one być jeszcze ciągle wystarczające i pożyteczne w niektórych zastosowaniach (Mejor, 2012).

Wspomnianych wad pozbawione są graficzne języki nowej generacji, które za pomocą różnych tzw. widoków (ang. view) umożliwiają opisanie modelowanego bytu z różnych perspektyw. Elementy graficzne użyte w różnych widokach mają nierzadko wspólny mianownik i mogą być stosowane w więcej niż jednym widoku. Do najchętniej używanych języków tej nowej generacji należą BPMN (Chinosi \& Trombetta, 2012), IDEF (Hanrahan, 1995) oraz język UML (ang. Unified Modeling Language).

UML jest dojrzałym, a jednocześnie ciągle aktywnie rozwijanym (ostatnia jego specyfikacja w wersji 2.5 opublikowana została w czerwcu 2015 r.) graficznym językiem opisu o uniwersalnym zastosowaniu. Początkowo był tworzony głównie na potrzeby informatyków, dzisiaj stanowi doskonałe narzędzie do modelowania zjawisk, procesów czy struktur w różnych dziedzinach. Powstał na bazie koncepcji metod obiektowych, które narodziły się we wczesnych latach 90. XX w. w wyniku scalenia kilku istniejących i często używanych notacji zaproponowanych przez Grady'ego Boocha i Jamesa Rumbaugha. Prace rozpoczęte w sierpniu 1994 r. prowadzone w firmie Rational Software Corporation (włączonej w 2003 r. do firmy IBM) zaowocowały najpierw ustaleniem standardu (czyli de facto gramatyki) notacji, a następnie połączono metody opisu Grady'ego Boocha (Booch Method), Jamesa Rumbaugha (Object Modeling Technique) i Ivara Jacobsena (Object-Oriented Software Engineering) oraz kilka innych w jeden język, którego specyfikację opublikowano w wersji 0.9 w czerwcu 1996 r. Aktualną specyfikację UML w wersji 2.5, opublikowano online ${ }^{2}$ (OMG, 2015) na blisko 800 stronach, przedstawiając ją w sposób formalny, nierzadko przy pomocy samego języka UML.

Samo rozwinięcie skrótu UML wskazuje, że jest to uniwersalny język modelowania, który można stosować do opisu dowolnego fragmentu istniejącej rzeczywistości. Uniwersalność UML ilustruje rysunek 1, pokazujący typy diagramów zdefiniowane w standardzie UML.

Wszystkie diagramy dzieli się na te, które opisują strukturę (służą do opisu strukturalnego) oraz te, które opisują zachowanie (służą do opisu behawioralnego). Wśród diagramów strukturalnych znajduje się diagram klas i jest to typ diagramu, który właśnie analizujemy (jest to przykład opisywania językiem UML konstrukcji języka UML). Wśród diagramów opisujących zachowanie znajduje się diagram aktywności (zwany też diagramem czynności), służący najczęściej do opisu kolejności i warunków czynności składających się na

${ }^{2}$ Pod adresem: http://www.omg.org/spec/UML/2.5/ 
realizację danego przepisu/algorytmu. Do diagramów zachowania należą też: diagramy interakcji (pokazujące interakcje, w które wchodzą między sobą obiekty danych klas w celu realizacji określonych celów), diagram przypadków użycia (służący do definiowania celów osób/podmiotów będących beneficjentami/składnikami danego systemu) oraz diagram stanów (opisujący stany, w jakich może znaleźć się obiekt danej klasy w ciągu całego cyklu życia systemu). Wśród diagramów opisujących aspekty strukturalne wyróżniono diagram klas (opisujący zależności między klasami bytów modelu), diagram obiektów (opisujący zależności między konkretnymi bytami), diagram profili (służący wizualizacji semantyki języka), diagram struktur złożonych (pokazujący wewnętrzną strukturę klasy i możliwości jej współpracy z innymi klasami), diagram komponentów (służący do „wysokopoziomowej” wizualizacji składowych modelowanego systemu), diagram wdrożenia (pokazujący fizyczne rozmieszczenie składowych w modelowanym systemie) oraz diagram pakietów (służący do wizualizacji podziału całego systemu na mniejsze w miarę niezależne od siebie fragmenty).

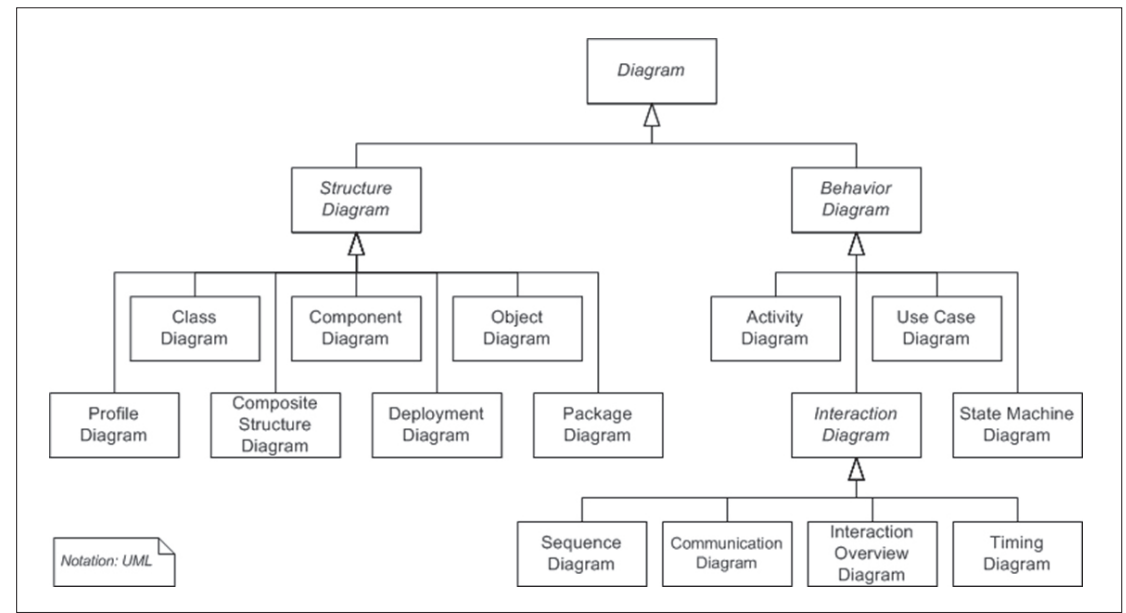

Rys. 1. Typy diagramów zdefiniowane w standardzie UML.

Źródło: https://upload.wikimedia.org/wikipedia/commons/d/d6/Uml_diagram2.png

Szczegółowy opis zastosowania poszczególnych diagramów wykracza poza ramy niniejszego opracowania, ale znaleźć go można w wielu publikacjach w postaci bardziej przyjaznej niż w źródłowej specyfikacji (np. Fowler, 2004).

Mimo że język UML znalazł do tej pory największe zastosowania w różnych dziedzinach nauk informatycznych, to stosuje się go również często w innych dziedzinach inżynieryjnych. Powodem takiego stanu rzeczy jest łatwość jego przyswojenia, czytelność, stopień rozpowszechnienia i zwięzłość przekazu. Autorka, opierając się na własnych doświadczeniach zdobytych podczas realizacji badań bibliometrycznych, przekonała się o jego praktycznej przydatności i zaletach wynikających z możliwości zastosowania wszędzie tam, gdzie wymagana jest precyzja i zwięzłość przekazu. 


\section{Przykład zastosowania UML do opisu pojęć z dziedziny bibliologii i informatologii}

W celu przybliżenia języka UML i zachęcenia czytelnika do jego stosowania, w dalszej części artykułu przedstawione zostały podstawowe idee stojące za opisem złożoności struktury przy pomocy diagramów klas.

Jak piszą Booch, Rumbaugh i Jacobson (Booch et al., 2002, 47):

Klasy to najważniejsze bloki konstrukcyjne wszystkich systemów obiektowych. Klasa jest opisem zbioru obiektów, które mają takie same atrybuty, operacje, związki i znaczenie.

Większość podręczników języka UML właśnie od diagramu klas rozpoczyna omawianie poszczególnych technik notacji graficznych. Na przykładzie identyfikacji form wydawniczych publikacji naukowych omówione zostaną podstawowe konstrukcje gramatyczne, które pozwolą wprowadzić czytelnika w świat klas i relacji.

Jak można wyczytać w Międzyinstytucjonalnym przewodniku redakcyjnym ${ }^{3}$ (European Union \& Office for Official Publications, 2011, 81-82):

\section{Wydawnictwa zwarte}

Zgodnie z normą ISO 2108:2005 (ISBN) wydawnictwo zwarte to wydawnictwo nieperiodyczne, publikowane jako całość w jednej części lub w kilku częściach (wydanych jednocześnie lub niejednocześnie). Wydawnictwa zwarte mogą być rozpowszechniane w dowolnej formie (książki drukowane w twardej lub miękkiej oprawie, książki na kasetach lub płytach CD i DVD, publikacje w języku Braille'a, publikacje w internecie, książki elektroniczne itp.).

Wydawnictwa zwarte wielotomowe składają się z określonej liczby osobnych tomów (wyjątkiem mogą być wydawnictwa zeszytowe). Wydawnictwa te są przewidziane i wydawane jako całość. Poszczególne części mogą mieć własne tytuły i informacje o odpowiedzialności.

Każdemu wydawnictwu zwartemu nadawany jest określony międzynarodowy znormalizowany numer książki ISBN (...).

\section{Wydawnictwa ciągłe}

Zgodnie z normą ISO 3297:2007 (ISSN) wydawnictwo ciągłe to wydawnictwo rozpowszechniane na dowolnym nośniku, publikowane w częściach - zwykle oznaczonych numerycznie lub chronologicznie - ukazujących się w określonych lub nieokreślonych odstępach czasu, bez ustalonego z góry terminu zakończenia. Do wydawnictw ciągłych zalicza się również wydania stale aktualizowane. (...) Wydawnictwa ciągłe obejmują m.in.:

wydawnictwa periodyczne i seryjne, publikowane w następujących po sobie lub osobnych częściach, bez ustalonego terminu zakończenia, zwykle oznaczone numerami (gazety, czasopisma, magazyny drukowane lub elektroniczne, roczniki, np. sprawozdania czy informatory, serie wydawnictw zwartych); wydania stale aktualizowane, których treść jest na bieżąco uaktualniana, bez ustalonego terminu zakończenia (bazy danych, uaktualniane na bieżąco wydawnictwa luźnokartkowe lub wydania internetowe, np. niniejszy Przewodnik w wersji on-line).

Uwaga:

Seria wydawnicza to zbiór osobnych publikacji, z których każda posiada własny tytuł, ale wszystkie są opatrzone wspólnym tytułem obejmującym całość serii (tzw. tytułem serii). Poszczególne publikacje mogą być oznaczone numerem lub nie.

Każdemu wydawnictwu ciągłemu nadawany jest określony międzynarodowy znormalizowany numer wydawnictw ciągłych ISSN.

\footnotetext{
${ }^{3}$ Przewodnik jest również dostępny pod adresem: http://publications.europa.eu/code/pl/pl-240300.htm
} 


\begin{abstract}
Wydawnictwa ciągłe i zwarte
Niektóre publikacje będące częścią wydawnictwa ciągłego (np. roczniki i wydawnictwa zwarte wydane w ramach serii) można dodatkowo traktować jako wydawnictwa zwarte (np. w celu udostępnienia ich zarówno oddzielnie, jak i w prenumeracie).

Publikacje takie należy przede wszystkim uznać za wydawnictwa ciągłe i nadać im numer ISSN (tytuł serii). Następnie należy nadać im numer ISBN (tytuł tomu)".
\end{abstract}

Przedstawiony w zacytowanych definicjach i opisach model pojęciowy przedstawiono za pomocą diagramu klas UML (Rys. 2).

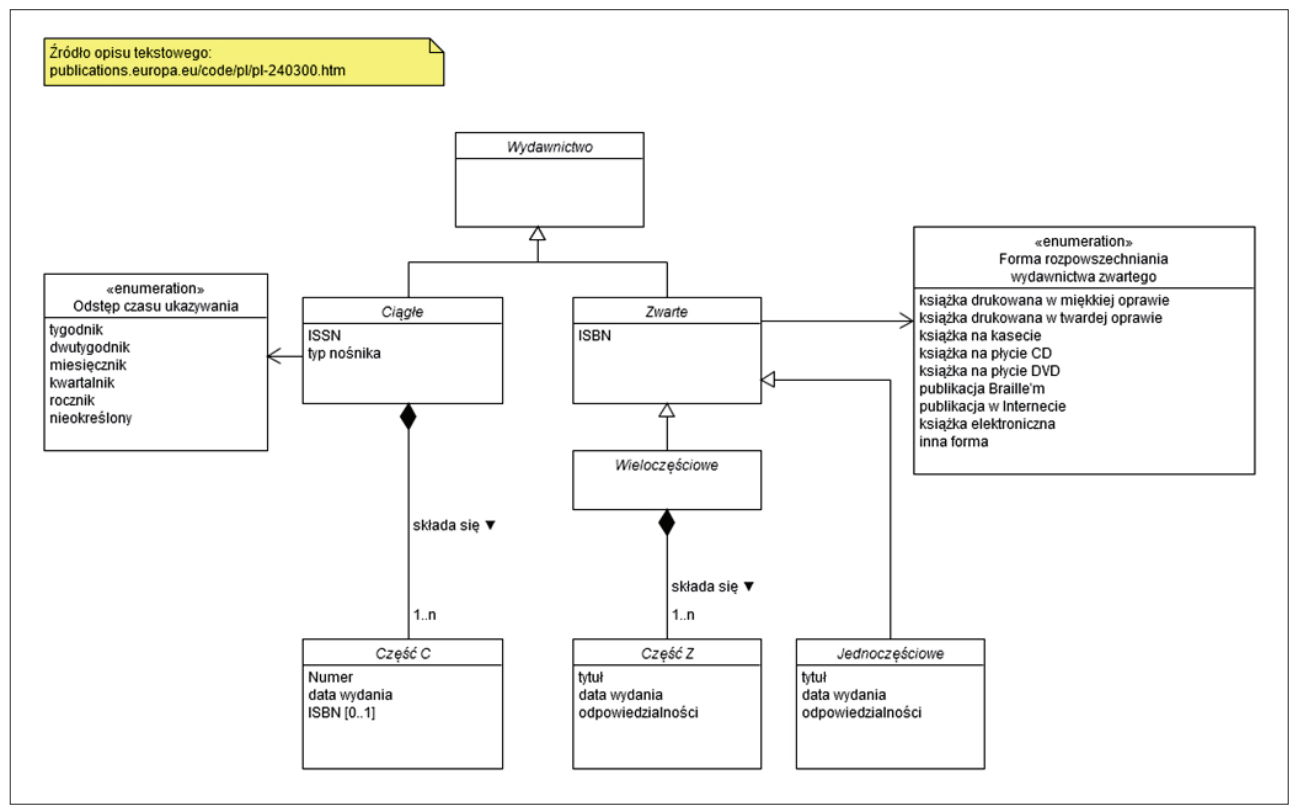

Rys. 2. Diagram klas kategoryzacji wydawnictw

Diagram można zacząć „czytać” od prostokąta Wydawnictwo. Prostokąty na diagramie klas reprezentują klasy, czyli w tym przypadku pojęcia, których znaczenie chcemy uchwycić graficznie. Nazwa wspomnianej klasy napisana jest kursywą, co oznacza, że jest to klasa abstrakcyjna, czyli taka, która ze względu na swoją ogólność nie może zostać zmaterializowana. Warto tutaj wspomnieć, że fizyczne rozmieszczenie jakichkolwiek elementów graficznych, długości czy sposoby załamania poszczególnych linii, w świetle definicji gramatyki języka UML nie mają znaczenia i nie niosą żadnych informacji. Jednak, podobnie jak w języku mówionym, na zrozumiałość przekazu wpływa nie tylko gramatyka i semantyka, ale również forma wypowiedzi - kolejność użycia poszczególnych części zdania, sposób kładzenia akcentów itp. W tym konkretnym przypadku strzałka skierowana w stronę klasy Wydawnictwo i brak strzałek od niej wychodzących sugerują, że jest to najbardziej ogólne pojęcie, od którego warto zaczać analizę diagramu. W demonstrowanym przykładzie wrażenie to pogłębiono stosując dodatkowo konwencję zgodną z przyzwyczajeniem do czytania tekstów z góry do dołu i umieszczając tę klasę na górze diagramu. Do tego typu dodatkowych konwencji należy też użycie kolorowania elementów graficznych. 
Analizując tekst źródłowy opisu kategoryzacji wydawnictw widzimy, że wydawnictwa dzielą się na zwarte i ciągłe (układ tekstu sugeruje, że są to kategorie rozłączne) i takie właśnie klasy zostały wydzielone na diagramie. Z klasą Wydawnictwo łączy je związek specjalizacji (zamknięta strzałka), co oznacza, że klasy te „dziedziczą” wszystkie cechy klasy bazowej, a dodatkowo rozszerzają je o swoje własne cechy. Jak czytamy w tekście źródłowym, wydawnictwa zwarte (informację o nieperiodyczności pominiemy z braku jej doprecyzowania) publikowane są w jednej lub wielu częściach (wydanych jednocześnie lub niejednocześnie). Charakterystykę tę odzwierciedlają dwie klasy Jednoczęściowe i Wieloczęściowe. Na końcu akapitu opisującego wydawnictwa zwarte czytamy, że każdemu wydawnictwu zwartemu nadawany jest numer ISBN, stąd na diagramie obecność tego atrybutu właśnie w klasie Zwarte. Wspomniane zostają formy publikacji wydawnictw, jednak z tekstu nie wynika, czy publikacja następuje w jednej z podanych form, czy też możliwa jest publikacja w kilku formach. Z tekstu nie wynika też czy w przypadku wydawnictw wieloczęściowych każda z części może być opublikowana w innej formie. Na diagramie lista możliwych form publikacji przedstawiona została jako klasa o stereotypie enumeration, a wartości tej listy jako lista jej atrybutów. Stereotypy to sposoby nadawania klasom szczególnych znaczeń, a stereotyp enumeration jest typowym i najczęstszym sposobem wyrażania typów wyliczeniowych, czyli takich, których wartości stanowią ograniczony zbiór nazwanych elementów. Klasę Zwarte łączy relacja nawigacji (strzałka otwarta) z klasą Forma Rozpowszechniania Wydawnictwa Ciagtego, co oznacza, że jeden z atrybutów tej klasy wyliczeniowej jest skojarzony z klasą Zwarte.

W tekście źródłowym można dalej przeczytać, że wydawnictwa zwarte wielotomowe składają się z określonej liczby osobnych tomów (wprowadzenie terminu tomu znowu jest tutaj mylące i niepotrzebne wobec wcześniejszego używania terminu wydawnictw jedno- i wieloczęściowych - termin ten zatem zostanie pominięty). Stąd na diagramie klasa Część Z(wartego) jest w relacji kompozycji (linia zakończona zaczernionym rombem) z klasą Wieloczęściowe. Związek kompozycji jest szczególnym przypadkiem związku agregującego, wskazującym na fakt, że obiekt klasy Czesśc $Z$ nie może zaistnieć jako samodzielny byt, bez wcześniejszego powołania obiektu klasy Wieloczęściowe. Związek ten został opisany wyrażeniem Składa się zapożyczonym wprost z tekstu źródłowego, a dla precyzji dodano strzałkę wskazującą kierunek interpretacji tego wyrażenia.

Jak wynika z dalszej części tekstu źródłowego, każda część wydawnictwa zwartego może mieć własne tytuły czy informacje o odpowiedzialności. Tę charakterystykę odzwierciedlają atrybuty dodane do klasy $C z e s s c ́$ $Z$. Warto zauważyć, że tekst nie precyzuje, że wydawnictwa jednoczęściowe powinny zawierać informacje o tytule czy odpowiedzialnościach. Z tekstu wynika, że wydawnictwa ciągłe (informację o periodyczności pominięto z tych samych względów co wcześniej) to wydawnictwa publikowane na dowolnym nośniku (dlaczego nie można się tu odwołać do nośników zdefiniowanych już dla wydawnictw zwartych?), publikowane w częściach. Przedstawia to klasa Części $C$, opatrzona, zgodnie z dalszym fragmentem tekstu, atrybutem opisu numerycznego bądź chronologicznego.

Po charakterystyce wydawnictw periodycznych i stale aktualizowanych następuje uwaga, w której wspomina się o seriach wydawniczych jako o zbiorze osobnych publikacji posiadających tytuł wspólny i tytuł każdej osobnej publikacji - nie wspominając wcześniej nic o sposobie nadawania tytułów dla publikacji ciągłych. Ponieważ każdemu wydawnictwu ciągłemu nadawany jest numer ISSN, na diagramie atrybut go reprezentujący dodany został 
do klasy Ciagłe. Klasa wyliczeniowa Odstęp czasu ukazywania pozwala zakwalifikować wydawnictwo ciągłe do odpowiednich kategorii.

Ostatnia uwaga o możliwości nadawania niektórym częściom publikacji ciągłych numerów ISBN została uwzględniona poprzez dodanie odpowiedniego atrybutu do klasy Część C z użyciem notacji [0...1] wskazującej, że wartość tego atrybutu jest opcjonalna (może wystąpić raz lub wcale).

Tak skonstruowany diagram pozwala na łatwą i szybką orientację w zależnościach między pojęciami oraz ich atrybutami. Sprzyja to analizie abstrakcyjnej, porządkowaniu informacji i wprowadzaniu odpowiednich poprawek.

Rysunek 3 zawiera diagram obrazujący jedną z możliwości dokładniejszego opisu przykładowej dziedziny. Przedstawia on poprawiony model pojęciowy, opisujący formy i zasady publikacji wydawnictw ciągłych i zwartych. Należy podkreślić, że u podstaw istoty modelowania leży często potrzeba przekazania obrazu rzeczywistości z pewnej perspektywy, a więc ujawniającego wszystkie istotne szczegóły, a pomijającego detale nieistotne z punktu widzenia celu budowy modelu. Często lepiej zbudować kilka mniejszych diagramów, ukazujących dziedzinę z różnych perspektyw niż próbować umieścić wszystko na jednym diagramie.

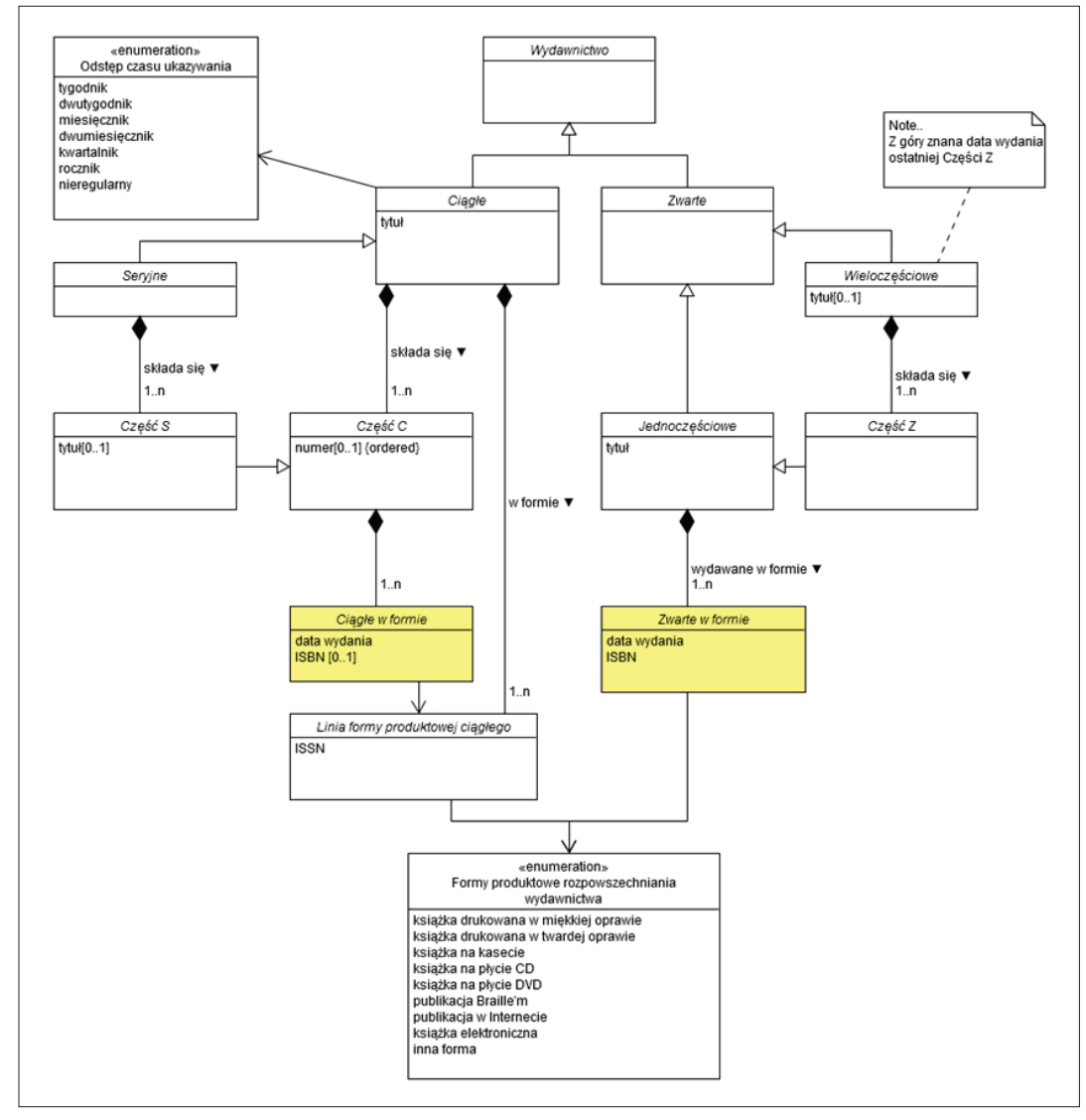

Rys. 3. Diagram klas poprawionej kategoryzacji wydawnictw 
Przedstawiony diagram nie ujawnia zależności związanych z autorstwem, redakcją, korektą czy innymi rodzajami odpowiedzialności. Nie opisuje również wewnętrznej struktury danego wydawnictwa, na którą składają się rozdziały, spisy treści itp., choć oczywiście opisanie tych zależności podobnym diagramem jest możliwe.

Należy również mieć na uwadze, że opatrzenie wydawnictw numerem ISBN bądź ISSN nie jest w żaden sposób obligatoryjne, a jedynie zalecane w celu uporządkowania rynku wydawniczego. Procedury wynikające z norm czy określane przez poszczególne jednostki zarządzające tymi numerami są jedynie zaleceniami, a poszczególni wydawcy zaopatrujący się z góry w pule tych numerów, zarządzają nimi samodzielnie nie podlegając w zasadzie żadnej kontroli, co często prowadzi do wielu anomalii. Taki stan rzeczy nie musi wynikać ze złej woli wydawców, a jedynie z bałaganu informacyjnego, który mógłby być uporządkowany przez bardziej precyzyjne opisanie zaleceń, tak w formie słownej jak i graficznej.

Diagram należy „czytać” następująco: wydawnictwa dzielą się na dwie podstawowe kategorie - wydawnictwa ciągłe i wydawnictwa zwarte. Wydawnictwa zwarte mogą być publikowane jako jednoczęściowe o określonym tytule i wydawane w jednej lub wielu różnych formach produktowych rozpowszechniania, z których każda ma odrębny numer ISBN i datę wydania. Wśród form produktowych rozpowszechniania wydawnictw wymienić można:

- druk w miękkiej oprawie;

- druk w twardej oprawie;

- płyta CD;

- inne.

Drugą kategorią wydawnictw zwartych są wydawnictwa wieloczęściowe. Poszczególne ich części wydawane są dokładnie na tych samych zasadach co wydawnictw jednoczęściowych, a różnić je może jedynie istnienie wspólnego tytułu obejmującego wszystkie części składowe. W przypadku wydawnictw wieloczęściowych znana jest z góry przewidywana data wydania ostatniej części (na diagramie opisuje to symbol notatki, którego można użyć do definiowania ograniczeń w sposób bardziej lub mniej formalny).

Wydawnictwa ciągłe natomiast to takie, które ukazują się cyklicznie pod wspólnym tytułem, w określonych bądź nieregularnych odstępach czasu. Każde wydawnictwo ciągłe może być publikowane w jednej lub wielu liniach formy produktowej rozpowszechniania, z których każda powinna posiadać odrębny numer ISSN. Poszczególne części wydawnictwa ciągłego mogą być opatrzone numerem kolejnym (na diagramie wyraża to notka \{ordered\}) i każda $\mathrm{z}$ tych części może być opublikowana w ramach wybranych linii formy produktowej, z określoną datą wydania i możliwością nadania oddzielnych numerów ISBN dla każdej linii z osobna. Szczególnym przypadkiem wydawnictw ciągłych są wydawnictwa seryjne składające się z części wydawanych na dokładnie tych samych zasadach co części wydawnictw ciągłych, ale z możliwością nadania osobnych tytułów dla każdej z części.

\section{Wnioski}

Początkowo niedoskonałe próby wypracowania graficznych narzędzi komunikacji międzyludzkiej zaowocowały ostatecznie powstaniem m.in. języka uniwersalnego - UML, który z wykorzystaniem prostych i intuicyjnych notacji umożliwia opisywanie złożonych systemów czy tworzenie ich modeli w różnych perspektywach. 
Celem powstania języka UML nie było zastąpienie żadnych innych używanych powszechnie notacji graficznych, w szczególności tych opisujących ilościowe aspekty systemów czy wyniki i rezultaty badań. W takich przypadkach skuteczniejsze są inne techniki przedstawiania informacji w postaci wizualnej, jak np. różnego rodzaju wykresy czy mapy prezentujące opisywaną rzeczywistość. Odległości pomiędzy poszczególnymi elementami graficznymi reprezentującymi opisywane byty, proporcje ich wielkości czy kolory użyte dla poszczególnych elementów graficznych pozwolą lepiej zobrazować zależności opisywanej i „mierzonej” dziedziny. Wszędzie natomiast tam, gdzie pożądana jest precyzja przekazu, a więc np. w przypadku badań naukowych, prac inżynieryjnych, organizacji i zarządzania, a także projektowania metod i narzędzi wykorzystywanych w działalności bibliotecznej i informacyjnej, warto rozważyć wykorzystanie UML.

Warto tutaj zauważyć, że język UML, podobnie jak inne języki graficzne służące modelowaniu dziedzin, czy inne notacje graficzne umożliwiające przedstawianie ilościowego czy jakościowego charakteru danych (czyli ich tzw. wizualizacji), czy też wreszcie języki naturalne, stanowią jedynie narzędzia w rękach ich użytkowników. Skuteczność komunikacyjna każdego języka w praktyce zależy nie tylko od jego budowy, ale również od umiejętności jego wykorzystania przez stronę komunikującą oraz poziomu percepcji strony komunikowanej, a te zależeć mogą od takich czynników jak:

- stopień znajomości budowy danego języka;

- stopień znajomości dziedziny przedmiotowej, do opisu której użyto danego języka;

- uwarunkowania kulturowe (kierunek czytania komunikatów, sposób interpretacji barw, itp.);

- $\quad$ stopień rozpowszechnienia danego języka;

- przyzwyczajenia wynikające z wcześniej wykorzystywanych metod komunikacji.

Wszystko to sprawia, że bardzo trudno, o ile w ogóle byłoby to możliwe, w sposób formalny dowodzić wyższości jednego narzędzia komunikacyjnego nad drugim, czy też stawiać się w roli arbitra rozsądzającego celowość wykorzystania danego narzędzia w konkretnym przypadku. Duża i nadal rosnąca popularność języka UML w dziedzinach technicznych pozwala sadzić, że język ten może być też użyteczny w opracowywaniu nowych metod i narzędzi dla bibliotekarstwa i usług informacyjnych, zwłaszcza takich jak kategoryzacje, modele semantyczne, taksonomie, modele dziedzinowe czy ontologie.

Przykłady praktycznego wykorzystania elementów języka UML w dziedzinie naukometrii znaleźć już można np. w opracowaniu autorki dotyczącym definicji struktury modelu analitycznego zastosowanego do budowy narzędzia wspierającego analizę cytowań (Kamińska, 2018a), jak również w artykule poświęconym grafowym reprezentacjom danych opisujących dziedzinę publikowania (Kamińska, 2018c).

\section{Bibliografia}

Booch, G., Rumbaugh, J., Jacobson, I. (2002). UML przewodnik użytkownika. Warszawa: Wydaw. Naukowo-Techniczne.

Chen, P. (1976). The Entity-Relationship Model: Toward a Unified View of Data. ACM Transactions on Database Systems, 1(1), 9-36.

Chen, P. (2002). Entity-Relationship Modeling: Historical Events, Future Trends, and Lessons Learned. In: M. Broy \& E. Denert (eds.) Software Pioneers (296-310). Berlin: Springer Verlag. 
Chinosi, M., Trombetta, A. (2012). BPMN: An introduction to the standard. Computer Standards E Interfaces, 34(1), 124-134.

Dietsch, D., Arenis, S. F., Westphal, B., Podelski, A. (2011). Disambiguation of industrial standards through formalization and graphical languages. 2011 IEEE 19th International Requirements Engineering Conference (265-270). DOI: 10.1109/RE.2011.6051634

Drabik, L., Sobol, E. (2016). Stownik języka polskiego. Warszawa: Wydawnictwo Naukowe PWN.

European Union, Office for Official Publications. (2011). Międzyinstytucjonalny przewodnik redakcyjny. Luksemburg: EUR-OP.

Fowler, M. (2004). UML Distilled: A Brief Guide to the Standard Object Modeling Language. Harlow: Addison-Wesley.

Gilbreth, F., Gilbreth, L. (1921). Process Charts: First Steps in Finding the One Best Way to do Work. ASME Transactions, 43(1818), 1029-1050.

Hanrahan, R. P. (1995). The IDEF Process Modeling Methodology [online]. Software Technology Support Center, [31.10.2017], http://www.sba.oakland.edu/faculty/mathieson/mis524/resources/ readings/idef/idef.html

Kamińska, A. M. (2017a). OpenCitations (I4OC) - otwarty indeks cytowań publikacji naukowych [online]. Biuletyn EBIB, 6(176), [29.08.2018], http://open.ebib.pl/ojs/index.php/ebib/article/ view/551/746.

Kamińska, A. M. (2017b). ProBIT - prospektywna metoda tworzenia trawersowalnych indeksów cytowań a współczesne problemy organizacji przestrzeni informacji w tradycyjnych bibliograficznych bazach danych. Zagadnienia Informacji Naukowej, 1(109), 66-82.

Kamińska, A. M. (2018a). ScientoMiner ICR - moduł importu danych bibliograficznych z zasobów Crossref dla platformy Gephi. Zagadnienia Informacji Naukowej, 1(111), 96-113.

Kamińska, A. M. (2018b). Wykorzystanie języka UML do eliminowania wieloznaczności w komunikatach naukowych. W: B. Sosińska-Kalata, P. Trafiłowski, Z. Wiorogórska (red.), Nauka o informacji w okresie zmian: innowacyjne ustugi informacyjne (69-85). Warszawa: Wydaw. SBP.

Kamińska, A. M. (2018c). Zastosowanie struktur grafowych do analiz bibliometrycznych i webometrycznych. Modele i metody. Nowa Biblioteka. Ustugi, Technologie Informacyjne i Media, 2(29), $47-63$.

Lamy, J. B., Duclos, C., Rialle, V., Venot, A. (2005). Which Graphical Approaches should be Used to Represent Medical Knowledge? Studies in Health Technology and Informatics, 116, 719-724.

Mejor, J. D. (2012). Przepływ danych w placówce informacyjnej call center. Zagadnienia Informacji Naukowej, 2(100), 100-119.

Olczyk, D. (2010). Modelowanie strukturalne - definicje, notacja, techniki i narzędzia. Zeszyty Naukowe Warszawskiej Wyższej Szkoty Informatyki, 4, 87-98.

OMG (2015). OMG Unified Modeling Language [online], [06.12.2016], http://www.omg.org/spec/ $\mathrm{UML} / 2.5 / \mathrm{PDF} /$

Piantadosi, S. T., Tily, H., Gibson, E. (2011). The communicative function of ambiguity in language. Cognition, 122(3), 280-291.

Slimani, T. (2015). Ontology development: A comparing study on tools, languages and formalisms. Indian Journal of Science and Technology, 8(24), 1-12. DOI: 10.17485/ijst/2015/v8i34/54249

Stanula-Boroń, M. (2001). Informacja, język i wiedza w ujęciu Karla R. Poppera. Zagadnienia Informacji Naukowej, 1(77), 3-16.

Stevens, W., Myers, G., Constantine, L. (1974). Structured Design. IBM Systems Journal, 13(2), $115-139$.

Tarełko, W. (2014). Zarys historii pojęć związanych z projektowaniem maszyn. Zeszyty Naukowe Politechniki Ślaskiej. Transport, 83(1904), 279-286.

Wit, E., Gillette, M. (1999). What is Linguistic Redundancy? Technical Report The University of Chicago [online], [06.12.2016], http://www.math.rug.nl/ ernst/linguistics/redundancy3.pdf 
Venot, A., Ouvard, P., Bar-Hen, A., Duclos, C., Lamy J. B. (2008). An iconic language for the graphical representation of medical concepts. BMC Medical Informatics and Decision Making, 8(1). DOI: $10.1186 / 1472-6947-8-16$

\title{
On the Development of Graphical Languages of Communication. An Example of the Use of UML in the Field of Book and Information Sciences
}

\begin{abstract}
Purpose/Thesis: The aim of the paper is to present the concept of Unified Modeling Language and discuss the possibilities of its application in the field of book and information sciences.

Approach/Methods: Based on the analysis of literature, the process of graphical languages development and their advantages related to the coherence and precision of communication are discussed. The case study of the categorization of publication forms is used to demonstrate the use of UML in modeling terms from the field of book and information sciences.

Results and conclusions: The presented example shows usefulness of UML for the development of new methods and tools in library and information services.

Originality/Value: Although UML is a tool widely used in many fields, the literature on information science has not analyzed yet its suitability for modeling of information tools and services.
\end{abstract}

Keywords

Communication. Graphical language. UML.

Dr ANNA MALGORZATA KAMIŃSKA jest adiunktem w Instytucie Bibliotekoznawstwa i Informacji Naukowej Uniwersytetu Ślaskiego w Katowicach oraz pracownikiem Biblioteki Głównej Politechniki Ślaskiej w Gliwicach. W 2016 r. obronita na Wydziale Filologicznym Uniwersytetu Ślaskiego w Katowicach rozprawę doktorska pt. Informacja naukowa o górnictwie w świetle wydawnictw ciągłych uczelni technicznych w Polsce (1945-1989). Jej zainteresowania naukowe skupiają się wokót trzech uzupelniających się obszarów: informatologia, graficzne języki komunikacji oraz wizualizacja informacji.

Kontakt $z$ autorka:

anna.kaminska@us.edu.pl

Instytut Bibliotekoznawstwa i Informacji Naukowej

Uniwersytet Ślaski w Katowicach

Plac Sejmu Ślaskiego 1

40-032 Katowice 